\title{
PERILAKU KECURANGAN AKADEMIK MAHASISWA AKUNTANSI : DIMENSI FRAUD PENTAGON (STUDI KASUS PADA MAHASISWA PRODI AKUNTANSI UKRIDA)
}

\author{
Kennedy Fadersair \\ Universitas Kristen Krida Wacana \\ kennedy.2015ea060@ civitas.ukrida.ac.id \\ Subagyo \\ Universitas Kristen Krida Wacana \\ subagyo@ukrida.ac.id
}

\begin{abstract}
This research examined factors that influence the behaviour of student's cheating by using the concept of fraud pentagon consisting of pressure, opportunity, rationalization, competence and arrogance. In collecting data using questionnaires with purposive sampling method. The regression model used in this study is the linear regression models with SPSS 24. Participants in this study were 122 accounting students in Faculty of Economics and Business Christian Krida Wacana University. The result of this research shows that simultaneously fraud pentagon have significant effect to student's academic fraud behavior. Partially, pressure and competence have positive significant effect to student's academic fraud behavior. Arrogance have negative significant effect to student's academic fraud behavior. Rationalization and opportunity did not influence.
\end{abstract}

Keyword : academic fraud, pressure, opportunity, rasionalization, capability, arrogance.

ABSTRAK: Penelitian ini untuk menguji faktor-faktor yang berpengaruh terhadap perilaku kecurangan akademik mahasiswa menggunakan konsep fraud pentagon, yaitu tekanan, kesempatan, rasionalisasi, kemampuan dan arogansi. Dalam pengumpulan data menggunakan kuesioner dengan metode purposive sampling. Model regresi yang digunakan dalam penelitian ini adalah model regresi linear berganda dengan bantuan SPSS 24. Sampel Penelitian sebanyak 122 mahasiswa Program Studi Akuntansi Fakultas Ekonomi dan Bisnis Universitas Kristen Krida Wacana. Hasil penelitian ini secara simultan menunjukkan bahwa fraud pentagon beperngaruh secara signifikan. Secara parsial menunjukkan bahwa tekanan dan kemampuan berpengaruh signifikan positif terhadap perilaku kecurangan akademik. Arogansi berpengaruh signifikan negatif terhadap perilaku kecurangan akademik. Rasionalisasi dan kesempatan tidak berpengaruh signifikan.

Kata kunci : kecurangan akademik, tekanan, kesempatan, rasionalisasi, kemampuan, arogansi.

\section{Pendahuluan}

Kecurangan akademik merupakan salah satu masalah yang cukup menggangu di masyarakat. Berdasarkan penelitian McCabe, dari sekitar 18.000 mahasiswa perguruan tinggi di Amerika Serikat dan Kanada, bahwa $70 \%$ melakukan kecurangan akademik (Stone, et al., 2010). Rangkuti (2011) melakukan penelitian dengan mahasiswa di

Universitas di Jakarta yang menunjukkan bahwa sebagian besar melakukan kecurangan akademik baik dalam ujian maupun ketika mengerjakan tugas. Dalam survey yang dilakukan oleh Litbang Media Group, kecurangan akademik yang dilakukan di tingkat sekolah menengah maupun di tingkat perguruan tinggi adalah menyontek 
(Pudjiastuti, 2012). Dapat kita mengartikan bahwa kecurangan akademik merupakan perilaku yang dilakukan dengan sengaja oleh pelajar, contohnya seperti melanggar aturan pengerjaan tugas ataupun ujian, membantu pelajar lain baik dalam pengerjaan tugas atapun ujian dengan cara yang tidak jujur (Cizek, 2003). Pada tahun 2010 terdapat 4 kasus besar dalam kecurangan akademik. Pertama ada pencabutan gelar dari guru besar karena menjiplak karya orang lain. Kedua lainnya penjiplakan mahasiswa tingkat sarjana oleh dua orang dosen untuk memperoleh gelar guru besar. Dan yang keempat karya ilmiah dari ilmuwan di Austria dijiplak oleh seorang guru besar (Susanti, 2017).

Mulyawati, et al. (2010) mengatakan bahwa kualitas pendidikan yang ada di Indonesia belum cukup bagus. Ini dapat dibuktikan dengan generasi muda yang dihasilkan lembaga pendidikan masih belum mencapai ekspetasi masyarakat. Banyak dari pribadi yang melakukan kecurangan akademik telah mengambil profesi sebagai contohnya polisi. Seperti pepatah "sedikit demi sedikit menjadi bukit" sama halnya kecurangan, jika dibiarkan dari kecil perlahan akan bertumbuh menjadi besar. Hal yang tidak diinginkan mungkin akan terjadi seperti halnya korupsi. Budaya menyontek bisa merusak integritas pendidikan dan bahkan menyebabkan perilaku yang cenderung dianggap sebagai tindakan kriminal.

Para ahli menjelaskan mengenai penyebab atau faktor-faktor dari kecurangan atau fraud. Berdasarkan Albrecht (2003) menyatakan bahwa terdapat tiga penyebab fraud, yaitu pressure, rationalization, dan opportunity. Wolfe dan Hermanson (2004) menyatakan bahwa diperlukan faktor keempat selain pressure, rationalization, dan opportunity yaitu capability. Keempat faktor ini dikenal dengan sebutan fraud diamond. Marks (2012) kembali menambahkan satu faktor yaitu arrogance dan ide tersebut dikenal dengan The Crowe's Fraud Pentagon.

Berdasarkan uraian diatas maka peneliti ini akan menjadikan topik pengaruh fraud pentagon terhadap kecurangan akademik sebagai bahan penelitian. Dimana yang membedakan dari penelitian terdahulu pada penelitian ini yaitu penambahan variabel arrogance. Penelitian ini akan diadakan di Universitas Kristen Krida Wacana Jakarta. Diharapkan dengan adanya penelitian ini dapat menjadi bahan pertimbangan untuk melakukan tindakan pencegahan kecurangan akademik khususnya di tingkat perguruan tinggi.

Berdasarkan latar belakang masalah yang telah diuraikan, maka dapat dirumuskan permasalahan sebagai berikut:

1. Apakah pressure berpengaruh terhadap kecurangan akademik?

2. Apakah rationalization berpengaruh terhadap kecurangan akademik?

3. Apakah opportunity berpengaruh terhadap kecurangan akademik?

4. Apakah competence berpengaruh terhadap kecurangan akademik?

5. Apakah arrogance berpengaruh terhadap kecurangan akademik?

Penelitian ini bertujuan untuk:

1. Mengetahui pengaruh pressure terhadap kecurangan akademik

2. Mengetahui pengaruh rationalization terhadap kecurangan akademik

3. Mengetahui pengaruh opportunity terhadap kecurangan akademik

4. Mengetahui pengaruh competence terhadap kecurangan akademik

5. Mengetahui pengaruh arrogance terhadap kecurangan akademik

\section{Kajian Pustaka \\ a. Kerangka Teori}

\section{Theory of Planned Behavior}

Ajzen (1991) mengatakan bahwa keputusan rasional yang dibuat oleh seorang individu dalam suatu tindakan tertentu didasarkan oleh keyakinan akan 
tindakan dan harapan mereka mendapat hasil positif setelahnya. Terdapat tiga hal yang mendasari keyakinan dan harapan sebagai inti dari Theory of Planned Behavior, yaitu :

1) Attitude toward the behavior, standar evaluasi dari perilaku seseorang entah itu positf atau negatif. Keyakinan akan hasil dari suatu perilaku akan menentukan sikap sesorang terhadap perilaku tersebut. Ketika seseoarng yakin suatu perilaku akan berdampak positif, maka orang tersebut akan cendrerung akan memilih perilaku tersebut. Hal ini disebut behavioral belief yaitu sikap seseorang terhadap suatu perilaku.

2) Subjective norm, sudut pandang sesorang mengenai tekanan sosial berpengaruh pada keputusan seseorang untuk melakukan sesuatu. Norma subjektif biasanya diturunkan dari keyakinan pada suatu norma dan motivasi untuk melalukan suatu perilaku. Hal ini sering disebut Normative belief.

3) Perceived behavioral control, sudut pandang seseorang mengenai tingkat kesulitan untuk melakukan sebuah perilaku. Terdapat faktor internal yaitu, informasi, kemampuan, keahlian dan emosi. Sedangkan untuk faktor eksternal terdapat kesempatan, sumber, dan ketergantungan pada orang lain.

Intention diasumsikan sebagai faktor motivasi yang memengaruhi perilaku, merupakan indikasi seberapa keras seseorang ingin untuk mencoba atau seberapa banyak usaha yang direncanakan akan dilakukan untuk melaksanakan perilaku yang terkait. Niat untuk berperilaku dapat menjadi perilaku sebenarnya hanya jika perilaku tersebut ada di bawah kontrol individu yang bersangkutan. Individu tersebut memiliki pilihan untuk memutuskan menampilkan perilaku tertentu atau tidak sama sekali
(Ajzen, 1991). Intention secara umum memiliki hubungan langsung dengan behavior.

Dengan adanya teori diatas kita dapat mengukur tingkat intensitas menyontek. Intesitas menyontek akan semakin besar ketika ada sikap positif terhadap perilaku menyontek, lalu perilaku menyontek sudah dianggap perilaku yang biasa dalam norma subjektif, kemudian adanya kontrol dari akibat yang ditimbulkan perilaku tersebut (Zamzam, et al., 2017)

\section{Kecurangan Akademik}

Menurut Davis, et al. (2009) perilaku dikatakan sebagai tindakan curang yang dilakukan murid ketika perbuatan tersebut bertujuan untuk mengecoh pengajar bahwa apa yang telah dikerjakan itu merupakan hasil dari siswa tersebut. Pendapat lain dari Anderman (2002) mengenai kecurangan yaitu tindakan yang tidak jujur ataupun tidak adil demi memperoleh suatu keuntungan.

Terdapat empat kategori utama kecurangan akademik menurut Eriksson dan McGee (2015) yaitu, pertama menggunakan bantuan secara sengaja untuk mendapat informasi yang tidak sah dalam suatu ujian. Kedua, memalsukan penemuan informasi atau kutipan. Ketiga, memberikan fasilitas kepada mahasiswa lainnya berupa bantuan yang terindikasi kecurangan akademik. Dan yang terakhir mengadopsi, mengutip ide dari orang lain dan menjadikannya sebagai ide miliknya tanpa mencatumkan nama dari penulis.

Suatu tindakan dinyatakan kecurangan akademik ketika sesuai dengan dua kriteria. Untuk kriteria pertama bantuan yang tidak diperbolehkan. Sebagai contoh yang sederhana yaitu menggunakan jasa joki dalam pengerjaan skripsi. Tapi perlu dipastikan kembali bahwa bantuan tersebut memang tidak diperbolehkan untuk digunakan. Kriteria selanjutnya yaitu jika perilaku tersebut berdampak positif terhadap nilai dari siswa tersebut. 
Sehingga dapat disimpulkan kecurangan akademik merupakan penerimaan atau penggunaan bantuan yang tidak diperkenankan untuk digunakan dalam pengerjaan tugas-tugas akademik (Anderman, 2002).

Menurut Wood dan Warnken (2004) terdapat 8 aktivitas yang dapat digolongkan sebagai kecurangan akademik, yaitu:

1) Plagiat, dimana hasil pekerjaan orang lain ditiru ataupun dikutip tanpa mencatumkan nama dari penulis sebelumnya dan mengakui bahwa itu merupakan karyanya.

2) Kolusi, dua pihak atau lebih bekerja sama untuk menyelesaikan suatu tugas ataupun ujian.

3) Falsification, mengakui pekerjaan orang lain sebagai hasil kerjanya.

4) Replikasi, demi mendapatkan kredit poin tambahan, tugas yang sama dimasukkan ke beberapa media atau tempat.

5) Penggunaaan catatan atau perangkat secara illegal.

6) Memperoleh baik soal maupun jawaban dari ujian.

7) Komunikasi antar peserta ujian ketika ujian sedang berlangsung

8) Menjadi perantara peserta yang melakukan kecurangan, atau membantu kecurangan dengan bepura-pura tidak tahu itu terjadi.

\section{Pressure}

Menurut Wolfe dan Hermanson (2004) yang dimaksud dengan tekanan ialah keadaan dimana seseorang terdesak dan perlu untuk melakukan kecurangan untuk melewatinya. Dan tekanan cenderung berasal dari orang-orang terdekat seperti orang tua, sahabat atapun saudara. Albrecht, et al. (2011) menjelaskan bahwa tekanan merupakan situasi keitika orang lebih memilih melakukan kecurangan dengan sadar. Terdapat beberapa faktor terjadinya kecurangan yaitu, sebagai berikut:

1. Faktor keuangan.

Tekanan yang berasal dari faktor keuangan biasanya orang cenderung memiliki hutang yang jumlahnya banyak, mengalami kerugian, dan kebutuhan keuangan yang tidak diprediksi. Faktor keuangan dapat menjadi penyebab seseorang untuk melakukan kecurangan akademik karena tidak mampu secara financial sehingga harus mendapatkan beasiswa agar dapat melanjutkan pendidikannya. Bonnie (2015) mengukur suatu keberhasilan dapat berupa nilai yang bagus, uang, mendapat beasiswa, dan pengakuan.

2. Kebiasaan buruk seseorang.

Kebiasaan buruk seseorang seperti menunda-nunda mengerjakan tugas dapat menjadi pengaruh untuk melakukan kecurangan akademik berupa menyontek.

3. Tekanan dari pihak eksternal

Sebuah tekanan untuk menjadi orang sukses dapat datang dari orang-orang terdekatnya seperti orang tua, saudara, dan teman-temannya sehingga orang tersebut tidak mementingkan kejujuran dan lebih mementingkan untuk melakukan kecurangan.

4. Tekanan lain

Tekanan lain dapat berupa gaya hidup seseorang. Untuk menjadi sukses, beberapa orang lebih memilih melakukan kecurangan daripada berbuat jujur.

Dikarenakan banyaknya tuntutan dan tugas yang harus dikerjakan mahasiswa merespon hal tersebut sebagai sebagai tekanan akademik (Robinson, 2013). Dalam jurnalnya Zamzam, et al. (2017) mengatakan bahwa tekanan akademik muncul ketika adanya desakan yang kuat baik dari dalam maupun dari lingkungan sekitarnya untuk memenuhi tuntutan dan tugas-tugas yang diberikan. Santoso dan Adam (2014) menyatakan bahwa dalam konteks kecurangan akademik, tekanan merupakan dorongan yang berhubungan masalah akademik seseorang untuk mendapatkan hasil yang terbaik bagaimanapun caranya. 


\section{Rationalization}

Menurut Wolfe dan Hermanson (2004) rationalization adalah adanya konflik di dalam diri pelaku kecurangan sebagai upaya pembenaran tindakan yang telah dilakukannya. Menurut Albrecht, et al. (2011) rasionalisasi merupakan pembenaran diri mengenai sesuatu yang salah dan melanggar peraturan seperti menganggap kecurangan hal biasa di sekelilingnya sering terjadi. Sedangkan menurut Eckstein (dalam Zamzam, et al. 2017) merupakan pembenaran perilaku sendiri dengan menyertakan alasan yang sebenarnya. Beberapa rasionalisasi yang sering terjadi di kalangan mahasiswa:

1) Dikarenakan sering melihat terjadinya di lingkungan sehingga merasa bahwa tidak pihak yang dirugikan.

2) Merasa kecurangan akademik merupakan hal yang biasa membuat mahasiswa menjadi tidak takut untuk melakukannya.

3) Tujuan baik dijadikan alasan untuk meraih nilai ataupun nama baik mahasiswa di lingkungan akademik.

\section{Opportunity}

Opportunity atau kesempatan merupakan situasi dimana seseorang melakukan kecurangan dikarenakan adanya peluang (Wolfe \& Hermanson, 2004). Opportunity merupakan peluang yang baik tercipta dengan sengaja maupun tidak disengaja ketika berada dalam situasi yang mendorong seorang mahasiswa untuk bertindak curang (Eckstein, 2003). Peluang adalah keuntungan yang diperoleh dari pihak luar (McCabe dan Trevino, 1997).

Albrecht et al. (2011) menjelaskan penyebab timbulnya kesempatan sebagai berikut:

1) Lemahnya internal control baik untuk mencegah maupun mendeteksi pelanggaran.

2) Disiplin yang gagal diterapkan kepada pelaku kecurangan akademik.

3) Pemeriksaan yang minim. Ketika hasil kerja tugas dan saat ujian berlangsung dosen atau pengawas tidak memeriksanya. Akibatnya mahasiswa berkesempatan untuk melakukan kecurangan.

\section{Competence}

Competence merupakan kemampuan seseorang untuk mengesampingkan internal control, mengembangkan strategi penyembunyian yang canggih, dan untuk mengendalikan situasi sosial untuk keuntungannya dengan menjualnya kepada orang lain (Marks, 2012). Wolfe dan Hermanson (2004) menjelaskan mengenai sifat-sifat dari faktor competence dalam pribadi pelaku kecurangan sebagai berikut:

1) Positioning: Jabatan yang dimiliki seseorang dalam suatu organisasi memberikan seseorang kesempatan untuk melakukan kecurangan. Semakin tinggi posisi jabatannya semakin besar juga pengaruhnya.

2) Intellegence and Creativity: Dengan pengetahuan dan pemahaman yang mumpuni pelaku akan dengan mudahnya memanfaatkan kelemahan internal control untuk melakukan kecurangan.

3) Convidence: Individu yakin tidak akan terdeteksi ketika dia memiliki rasa percaya diri dan ego yang kuat.

4) Coercion: Dapat diartikan sebagai memaksa. Ketika tindakan kecurangan diketahui oleh orang lain biasanya pelaku mencoba melakukan pendekatan persuasif sehingga tetap tersembunyi. Namun bila tidak mencapai titik temu pelaku pun harus memaksa orang tersebut untuk bungkam.

5) Deceit: Adanya pendeteksian mendorong pelaku kecurangan untuk mampu menipu dengan berbohong serta menjaga konsistensi dari kebohongan itu.

6) Stress: Mengendalikan stress sangat diperlukan oleh pelaku kecurangan untuk tetap menjaga agar tetap tersembunyi. 


\section{Marks Arrogance}

Marks (2012) menjelaskan bahwa arrogance atau kurangnya hati nurani

berlaku bagi dirinya. Lano (2015) mengatakan bahwa sikap arogan ditunjukan oleh sesorang yang merasa dirinya lebih dari orang lain. Achsin \& Cahyaningtyas (2016) juga mengatakan bahwa arrogance dapat muncul ketika seseorang merasa superiotas dalam dirinya atau mampu melakukan kecurangan tanpa ada kontrol yang dapat menggagalkan aksinya sehingga pelaku akan melakukan kecurangan tanpa adanya rasa takut sanksi yang menantinya.

Orang yang angkuh atau sombong dapat didefinisikan sebagai orang yang bertindak seolah-olah dia lebih tinggi, lebih berharga atau penting daripada yang lain dan meremehkan mereka. Namun, pada saat yang sama, orang yang sombong ingin dikagumi dan dihormati karena kualitas dan prestasinya yang istimewa. Arogansi menyiratkan keinginan untuk mendominasi dan keyakinan berlebihan pada kemampuan seseorang, serta melihat diri sendiri sebagai layak untuk sukses (Cerdán, 2017).

Tidak ada penyebab tunggal arogansi. Dalam beberapa kasus, seseorang dapat menjadi sombong karena pengalaman tertentu yang telah dijalaninya, tetapi di lain waktu tidak ada alasan atau penyebab psikologis yang dapat menjelaskannya. Dalam banyak kasus, seseorang menjadi arogan karena dia telah berhasil sejauh ini dan telah memenangkan pencapaian yang bagi orang lain sulit untuk dicapai. Melakukan sesuatu yang luar biasa yang hampir tidak ada yang dapat dicapai menstimulasi rasa harga diri kita, terkadang sampai pada titik melihat orang lain kurang penting. Ini karena kita membandingkan diri kita secara tidak sadar dengan orang lain sepanjang waktu, untuk mengukur kemajuan yang kita buat dalam apa yang penting bagi kita (Cerdán, 2017). merupakan sikap superioritas dan keserakahan dari bagian seseorang yang meyakini bahwa internal control tidak Arogansi berfungsi sebagai mekanisme pertahanan. Ini adalah cara untuk melindungi harga diri dan harga diri kita. Ini adalah cara untuk menyembunyikan dan mengkompensasi ketidakamanan, rendah diri, kurangnya kepercayaan diri. Kesombongan membantu kita menolak orang lain sebelum mereka menolak kita. Ini adalah cara untuk mencegah mereka menyakiti kita. Oleh karena itu, lebih umum untuk bersikap arogan terhadap orang asing, karena takut ditolak. Jika kita merasa tidak aman secara emosional, menunjukkan diri kita lebih superior daripada orang lain atau memamerkan kualitas atau prestasi kita akan membantu kita merasa lebih baik dalam jangka pendek. Namun, itu bukan strategi jangka panjang yang efektif, karena beberapa alas an yaitu, setelah kita sendirian, kita akan merasa tidak aman. Tidak seorang pun suka berada di sebelah seseorang yang arogan, sehingga orang-orang akan menjauh dari Anda, membuat Anda merasa lebih buruk dan lebih buruk. Mereka mungkin tidak menolak Anda tetapi Anda tidak akan memiliki hubungan atau ikatan yang intim yang dapat menyebabkan depresi (Cerdán, 2017).

Kesombongan membuat orang sangat peduli tentang apa yang orang lain pikirkan tentang mereka. Mereka bergantung pada persetujuan orang lain. Terkadang, orang-orang berperilaku arogan untuk mendapat perhatian bahwa mereka tidak bisa mendapatkan sebaliknya. Memang benar bagi orangorang yang karena arogan telah mendapatkan banyak perhatian di masa lalu, jadi mereka terus melakukannya. Dalam kasus ini, begitu mereka berhenti mendapatkan perhatian itu, mereka berhenti bersikap seperti itu (Cerdán, 2017). 


\section{b. Penelitian Sebelumnya}

Terdapat penelitan terdahulu yang berhubungan dengan faktor-faktor fraud pentagon dan kecurangan akademik. Fitriani dan Baridwan (2012) melakukan Penelitian mengenai penyebab perilaku kecurangan akademik mahasiswa akuntansi dari dimensi fraud triangle. Hasilnya pressure, rationalization dan opportunity berpengaruh positif terhadap kecurangan akademik. Nursani (2014) dalam penelitiannya menelusuri penyebab dari perilaku kecurangan akademik dari sisi fraud diamond. Hasilnya baik opportunity, rationalization dan comptence berpengaruh signifikan positif terhadap perilaku kecurangan akademik sedangkan pressure tidak bepengaruh signifikan. Zaini, et al. (2015) dalam penelitiannya dari dimensi fraud diamond melihat bahwa hanya pressure yang berpengaruh signifikan dalam kecurangan akademik pada mahasiswa di madura. Dalam penelitian yang dilakukannya pada mahasiswa S1, S2 dan S3 Universitas Brawjaya dengan dimensi fraud diamond, Dewi (2016) menemukan bahwa pressure, rationalization, opportunity dan competence berpengaruh signifikan terhadap perilaku kecurangan akademik. Penelitian juga dilakukan pada mahasiswa S1 di Ternate oleh Zamzam, et al. (2017) dengan perspektif fraud diamond. Hasilnya menunjukan bahwa pressure dan comptence berpengaruh signifikan terhadap perilaku kecurangan akademik. Sebaliknya rationalization dan opportunity tidak berpengaruh signifikan terhadap perilaku kecurangan akademik. Hariri, et al. (2018) juga melakukan penelitian dengan perspektif fraud diamond. Hasilnya menunjukan dimana secara simultan fraud diamond berpengaruh signifikan positif terhadap perilaku kecurangan akademik. Secara parsial rationalization, opportunity dan comptence berpengaruh signifikan positif terhadap perilaku kecurangan akademik. Sedangkan pressure tidak bepengaruh signifikan terhadap perilaku kecurangan akademik.

Tabel 2.1 : Penelitian Terdahulu

$\begin{array}{lll}\text { No Peneliti Judul Hasil } & \end{array}$

\begin{tabular}{|c|c|c|c|}
\hline 1 & $\begin{array}{c}\text { Fitriani dan Baridwan } \\
\text { (2012) }\end{array}$ & $\begin{array}{l}\text { Perilaku Kecurangan } \\
\text { Akademik Mahasiswa } \\
\text { Akuntansi: Dimensi Fraud } \\
\text { Triangle }\end{array}$ & $\begin{array}{l}\text { Pressure, } \\
\text { Rationalization dan } \\
\text { Opportunity } \\
\text { berpengaruh postif } \\
\text { pada kecurangan } \\
\text { akademik }\end{array}$ \\
\hline 2 & Dewi (2016) & $\begin{array}{l}\text { Perilaku Kecurangan } \\
\text { Akademik pada Mahasiswa } \\
\text { S1, S2, dan S3 Jurusan } \\
\text { Akuntansi FEB UB } \\
\text { berdasarkan Konsep Fraud } \\
\text { Diamond }\end{array}$ & $\begin{array}{l}\text { Pressure, } \\
\text { Rationalization, } \\
\text { Opportunity dan } \\
\text { Competence } \\
\text { berpengaruh positif } \\
\text { pada perilaku } \\
\text { kecurangan akademik }\end{array}$ \\
\hline 3 & Zamzam, et al. (2017) & $\begin{array}{l}\text { Pengaruh Diamond Fraud } \\
\text { dan Tingkat Religiutas }\end{array}$ & $\begin{array}{l}\text { - Pressure dan } \\
\text { competence }\end{array}$ \\
\hline
\end{tabular}


Analisis Pengaruh Diamond

Fraud dan Gone Theory Terhadap Academic Fraud (Studi Kasus

Mahasiswa Akuntansi SeMadura)

5

Nursani (2014)

Perilaku

Akademik Mahasiswa:

Dimensi Fraud Diamond berpengaruh terhadap perilaku

kecurangan akademik

- Rationalization dan opportunity tidak berpengaruh terhadap kecurangan akademik

- Pressure berpengaruh positif terhadap kecurangan akademik mahasiswa akuntansi.

- Opportunity, rationalization dan competence tidak berpengaruh terhadap kecurangan akademik mahasiswa akuntansi

- Oppprotuniy, Rationalization, dan Competence berpengaruh positif signifikan terhadap perilaku kecurangan akademik.

- Pressure tidak berpengaruh terhadap perilaku kecurangan akademik.

$6 \quad$ Hariri, et al. (2018)

Mendeteksi $\begin{array}{r}\text { Perilaku } \\ \text { Kecurangan Akademik } \\ \text { dengan Perspektif }\end{array}$ Fraud
Diamond Theory

- Fraud diamond secara simultan berpengaruh signifikan positif terhadap perilaku kecurangan akademik

- Rationalization, opportunity, dan 


\section{c. Pengembangan Hipotesis}

Menurut Wolfe dan Hermanson (2004) yang dimaksud dengan tekanan ialah keadaan dimana seseorang terdesak dan perlu untuk melakukan kecurangan untuk melewatinya. Dan tekanan cenderung berasal dari orang-orang terdekat seperti orang tua, sahabat atapun saudara. Dalam penelitiannya tentang kecurangan akademik mahasiswa akuntansi dengan fraud triangle sebagai indikator, Fitriani dan Baridwan (2012) menemukan bahwa pressure memiliki pengaruh positif terhadap kecurangan akademik pada mahasiwa akuntansi. Hasil ini diperkuat dengan penelitian Zaini, et al. (2015), Dewi (2016) dan Zamzam, et al. (2017) yang menunjukkan tekanan berpengaruh terhadap kecurangan akademik. Dapat disimpulkan bahwa semakin besar pressure yang diterima semakin besar juga dorongan untuk melakukan perilaku kecurangan akademik.

Berdasarkan uraian diatas dapat dirumuskan hipotesis sebagai berikut:

\section{$\mathrm{H}_{1}$ : Pressure berpengaruh positif terhadap kecurangan akademik}

Menurut Wolfe dan Hermanson (2004) rationalization adalah adanya konflik di dalam diri pelaku kecurangan sebagai upaya pembenaran tindakan yang telah dilakukannya. Sedangkan menurut Eckstein (dalam Zamzam, et al. 2017) merupakan pembenaran perilaku sendiri

\author{
Comptence secara \\ parsial \\ berpengaruh \\ signifikan positif \\ terhadap perilaku \\ kecurangan \\ akademik \\ - Pressure secara \\ parsial tidak \\ berpengaruh \\ signifikan terhadap \\ perilaku \\ kecurangan \\ akademik
}

dengan menyertakan alasan yang sebenarnya. Berdasarkan penilitian Fitriani dan Baridwan (2012) mengenai kecurangan akademik dan fraud triangle sebagai indikator ditemukan bahwa rationalization berpengaruh positif terhadap kecurangan akademik pada mahasiswa akuntansi. Hasil ini diperkuat dengan penelitian Nursani (2014) dan Dewi (2016) yang memperlihatkan bahwa rationalization memiliki pengaruh positif dalam kecurangan akademik. Dapat disimpulkan bahwa semakin besar tingkat rationalization yang ada semakin besar juga dorongan untuk melakukan perilaku kecurangan akademik.

Berdasarkan uraian diatas dapat dirumuskan hipotesis sebagai berikut:

\section{$\mathrm{H}_{2}$ : $\quad$ Rationalization berpengaruh positif terhadap kecurangan akademik}

Opportunity atau kesempatan merupakan situasi dimana seseorang melakukan kecurangan dikarenakan adanya peluang (Wolfe dan Hermanson, 2004). Kesempatan merupakan peluang yang baik tercipta dengan sengaja maupun tidak disengaja ketika berada dalam situasi yang mendorong seorang mahasiswa untuk bertindak curang (Eckstein, 2003). Fitriani dan Baridwan (2012) menemukan bahwa opportunity berpengaruh positif dalam jurnalnya mengenai kecurangan akademik dengan fraud triangle sebagai indikator. Hasil ini 
diperkuat dengan penelitian Nursani (2014) dan Dewi (2016) yang memperlihatkan bahwa opportunity memiliki pengaruh positif dalam kecurangan akademik. Dapat disimpulkan bahwa semakin besar opportunity yang ada semakin besar juga dorongan untuk melakukan perilaku kecurangan akademik. Berdasarkan uraian diatas dapat dirumuskan hipotesis sebagai berikut:

\section{$\mathrm{H}_{3}$ : Opportunity berpengaruh positif terhadap kecurangan akademik}

Competence merupakan kemampuan seseorang untuk mengesampingkan internal control, mengembangkan strategi penyembunyian yang canggih, dan untuk mengendalikan situasi sosial untuk keuntungannya dengan menjualnya kepada orang lain Marks (2012). Nursani (2014) dalam penelitiannya menemukan bahwa comptence memiliki pengaruh signifikan positif terhdap perilaku kecurangan akademik. Ini memperkuat penelitian Wolfe dan Hermanson (2004) yang mengatakan bahwa competence merupakan salah satu faktor dari perilaku keccurangan. Penelitian lain yang juga mendukung Dewi (2016), Zamzam, et al. (2017) dan Hariri, et al. (2018) yang menyatakan bahwa competence berpengaruh terhadap perilaku kecurangan akademik. Dapat disimpulkan bahwa semakin besar opportunity yang dimiliki seseorang semakin besar juga dorongan untuk melakukan perilaku kecurangan akademik.Berdasarkan uraian diatas dapat dirumuskan hipotesis sebagai berikut:

$\mathrm{H}_{4}$ : $\quad$ Competence berpengaruh positif terhadap kecurangan akademik

Marks (2012) menjelaskan bahwa arrogance merupakan sikap superioritas dan keserakahan dari bagian seseorang yang meyakini bahwa internal control tidak berlaku bagi dirinya. Lano (2015) mengatakan bahwa sikap arogan ditunjukan oleh sesorang yang merasa dirinya lebih dari orang lain. Achsin dan Cahyaningtyas (2016) mengatakan bahwa arrogance dapat muncul ketika seseorang merasa superior atau dirinya mampu melakukan kecurangan tanpa ada kontrol yang dapat mengagalkan aksinya sehingga pelaku akan melakukan kecurangan tanpa adanya rasa takut sanksi yang menantinya. Sehingga dapat disimpulkan semakin tinggi tingkat arrogance semakin besar juga dorongan dalam perilaku kecurangan akademik. Berdasarkan uraian diatas dapat dirumuskan hipotesis sebagai berikut:

$\mathrm{H}_{5}$ : Arrogance berpengaruh positif terhadap kecurangan akademik

\section{d. Rerangka Penelitian}

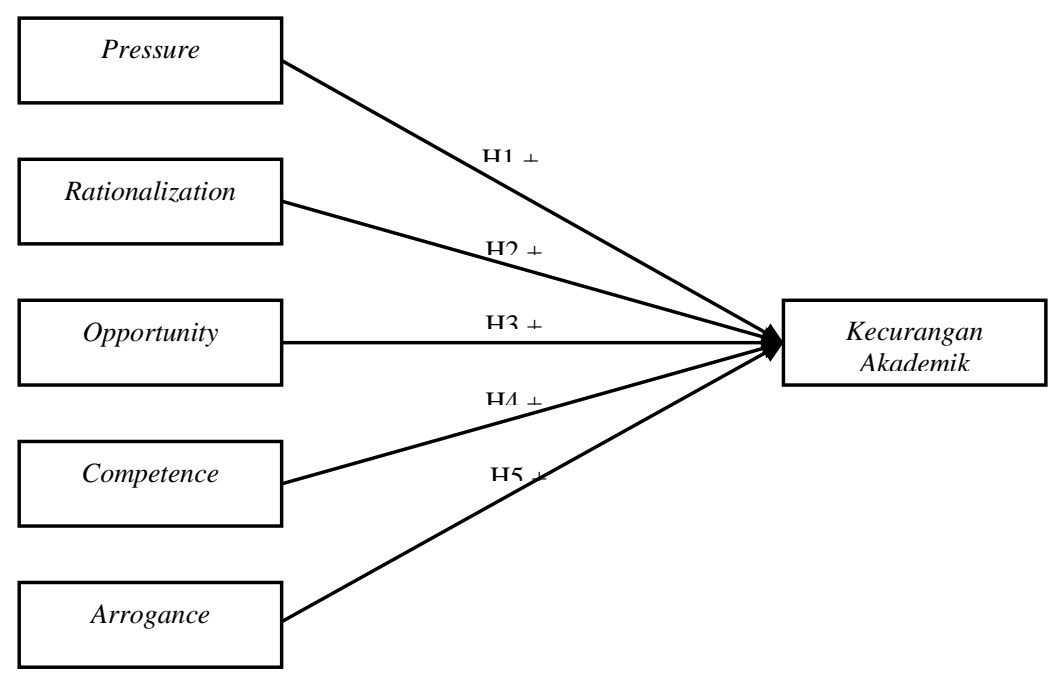




\section{Metode Penelitian}

\section{a. Jenis dan Sumber Data}

Jenis data yang digunakan dalam penelitian ini adalah data primer. Pada penelitian ini metode survey digunakan sebagai metode pengumpulan data. Survey merupakan metode pengumpulan data dimana kumpulan pertanyaan akan diberikan kepada responden individu (Jogiyanto, 2010). Kuesioner tertulis merupakan pengumpulan data yang dipilih dalam penelitian ini dan untuk menjaga kerahasiaan identitas responden penulis tidak melakukan wawancara langsung dikarenakan kecurangan akademk merupakan hal yang cukup sensitive. Dibutuhkan kurang lebih 1 bulan untuk pengumpulan data.

$$
\text { Dalam penelitian }
$$

ini pengklasifikasian didasarkan oleh tahun angkatan dengan asumsi bahwa mahasiswa senior memiliki lebih banyak pengalaman, termasuk pengalaman baik hanya mengetahui ataupun terlibat dalam kecurangan akademik. Hal ini didasarkan oleh mahasiswa tingkat akhir cenderung merasakan tekanan yang lebih besar dibandingkan tingkat lain. Kemudian koneksi yang dimiliki mahasiswa tingkat akhir lebih banyak sehingga memunculkan lebih banyak peluang. Untuk rasionalisasi dan kapabilitas cukup beragam mengenai perilaku kecurangan akademik sesuai dengan pengalamannya (Fitriani dan Baridwan, 2012).

\section{b. Populasi dan Sampel}

Pada penelitian ini, mahasiswa Prodi Akuntansi Fakultas Ekonomi dan Bisnis Universitas Kristen Krida Wacana Jakarta dijadikan sebagai populasi. Purposive sampling digunakan sebagai metode pengambilan sampel dalam penelitian ini. Sampel yang telah dipilih secara acak diklasifikasikan berdasarkan populasi ke kelompok saling eksklusif yang sesuai dengan konteks studi (Sekaran dan Bogey, 2013). Mahasiswa aktif dikelompokkan berdasarkan posisi semester yang sedang diambil yaitu semester 1, 3, 5 dan 7. Untuk jumlah sampel digunakan rumus Slovin dimana alfa penelitian sebesar $10 \%$. Sehingga menghasilkan jumlah sampel minimal sebanyak 81 mahasiswa.

$$
\mathrm{n}=\frac{427}{1+\left(427 \times 10 \%^{2}\right)}
$$

\section{c. Model Penelitian}

Berdasarkan populasi dan sampel dari penelitian diatas maka peneliti menggunalan analisis regresi berganda dengan model penelitian sebagai berikut:

$$
\begin{gathered}
\mathrm{KA}=\alpha+\beta_{1} \cdot \mathrm{PR}+\beta_{2} \cdot \mathrm{RA}+\beta_{3} \cdot \mathrm{OP}+\beta_{4} \cdot \mathrm{CO}+ \\
\beta_{5} \cdot \mathrm{AR}+\mathrm{e}(3.2)
\end{gathered}
$$

Dimana:

$$
\begin{array}{ll}
\text { KA } & =\text { Kecurangan Akademik } \\
& \text { OP = Opportunity } \\
\alpha & =\text { konstanta } \\
& \text { CO = Comptence } \\
\beta \quad & =\text { koefisien regresi } \\
& \text { AR = Arrogance } \\
\text { PR } \quad=\text { Pressure } & \text { e = Standar Error } \\
\text { RA } \quad=\text { Rationalization }
\end{array}
$$

\section{d. Operasionalisasi Variabel}

1. Variabel Dependen

Perilaku dikatakan sebagai tindakan curang yang dilakukan murid ketika perilaku tersebut bertujuan untuk mengecoh pengajar bahwa apa yang telah dikerjakan itu merupakan hasil dari siswa tersebut (Davis, et al., 2009). Indikator yang digunakan pada variabel kecurangan akademik yatiu, pertama menggunakan bantuan secara sengaja untuk mendapat informasi yang tidak sah dalam suatu ujian. Kedua, memalsukan penemuan 
informasi atau kutipan. Ketiga, memberikan fasilitas kepada mahasiswa lainnya berupa bantuan yang terindikasi kecurangan akademik. Dan yang terakhir mengadopsi, mengutip ide dari orang lain dan menjadikannya sebagai ide miliknya tanpa mencatumkan nama dari penulis.

\section{Variabel Independen}

Skala Likert digunakan untuk pengukuran kuesioner dengan 1 sampai 4 sebagai berikut: 1 untuk Sangat Tidak Setuju (STS), 2 untuk Tidak Setuju (TS), 3 untuk Setuju (S), 4 untuk Sangat Setuju (SS). Nilai tengah atau pilihan "tidak tahu/ragu-ragu/netral" tidak digunakan sehingga jawaban yang meragukan dapat terhindar jawaban yang meragukan, seperti yang dijelaskan pada penelitian Yudiana dan Lastanti (2016).

Menurut Wolfe dan Hermanson (2004) yang dimaksud dengan tekanan ialah keadaan dimana seseorang terdesak dan perlu untuk melakukan kecurangan untuk melewatinya. Dan tekanan cenderung berasal dari orang-orang terdekat seperti orang tua, sahabat atapun saudara. Indikator yang digunakan pada variabel pressure yaitu, materi kuliah sulit dipahami, soal ujian sulit, tuntutan orang untuk mendapat nilai bagus dan standar indeks prestasi.

Menurut Wolfe dan Hermanson (2004) rationalization adalah adanya konflik di dalam diri pelaku kecurangan sebagai upaya pembenaran tindakan yang telah dilakukannya. Indikator yang digunakan pada variabel rationalization yaitu, kecurangan akademik pernah dilakukan orang lain, plagiat menjadi hal yang lumrah, bentuk solidaritas dengan membantu orang lain saat ujian dan tidak ada pihak yang dirugikan.

Opportunity atau kesempatan merupakan situasi dimana seseorang melakukan kecurangan dikarenakan adanya peluang (Wolfe dan Hermanson, 2004). Indikator yang digunakan pada variabel opportunity yaitu, sanksi yang diberikan tidak berat, pengawas tidak menjaga ujian dengan ketat, copy paste tanpa menyebutkan sumber karena kemudahan internet, dan dosen jarang memeriksa satu-persatu tugas individu.

Competence merupakan seseorang mampu untuk menghindari pengawasan, mampu menyembunyikan kecurangan dengan rapih dan mengendalikan situasi untuk keuntungan pribadi bahkan dengan menjual keuntungan tersebut kepada orang lain (Marks, 2012). Indikator yang digunakan pada variabel competence yaitu, pelaku tidak memiliki rasa bersalah, mampu menemukan celah untuk melakukan kecurangan akademik, mampu menyelipkan dan menggunakan barang elektronik saat ujian dan pelaku mempunyai strategi khusus dalam melakukan kecurangan akademik.

Marks (2012) menjelaskan bahwa arrogance atau kurangnya hati nurani merupakan sikap superioritas dan keserakahan dari bagian seseorang yang meyakini bahwa internal control tidak berlaku bagi dirinya. Indikator yang digunakan pada variabel pressure yaitu, pelaku menggap dirinya telah melakukan sesuatu yang luar biasa, merasa kurang aman dan membutuhkan pengakuan dari orang lain.

Tabel 3.1 Operasional Variabel

\begin{tabular}{|c|c|c|c|}
\hline Variabel & Indikator & Skala & Referensi \\
\hline Kecurangan Akademik & $\begin{array}{l}\text { - } \text { Bantuan ilegal dalam } \\
\text { tugas atau ujian } \\
\text { - Pemalsuan Kutipan } \\
\text { - Perantara kecurangan }\end{array}$ & Ordinal & $\begin{array}{c}\text { Davis, et al. } \\
(2009)\end{array}$ \\
\hline
\end{tabular}




\begin{tabular}{|c|c|c|c|}
\hline Pressure & $\begin{array}{ll}\text { - } & \text { akademik } \\
& \text { nidak mencantumkan } \\
\text { - } & \text { Materi sulit dipahami } \\
\text { - } & \text { Soal ujian sulit } \\
\text { - } & \text { Tuntutan dari luar } \\
& \text { untuk mendapat nilai } \\
& \text { bagus } \\
\text { - } & \text { Standar indeks prestasi }\end{array}$ & Ordinal & $\begin{array}{l}\text { Wolfe dan } \\
\text { Hermanson } \\
\quad(2004)\end{array}$ \\
\hline Rationalization & $\begin{array}{l}\text { - Pernah dilakukan orang } \\
\text { lain } \\
\text { - } \text { Plagiat hal yang lumrah } \\
\text { - } \text { Bentuk solidaritas } \\
\text { - } \text { Tidak ada yang } \\
\text { dirugikan }\end{array}$ & Ordinal & $\begin{array}{l}\text { Wolfe dan } \\
\text { Hermanson } \\
\text { (2004) }\end{array}$ \\
\hline Opportunity & $\begin{array}{l}\text { - Sanksi kurang berat } \\
\text { - Pengawasan lemah saat } \\
\text { ujian } \\
\text { - Kemudahan dari } \\
\text { internet } \\
\text { - Tugas jarang diperiksa }\end{array}$ & Ordinal & $\begin{array}{l}\text { Wolfe dan } \\
\text { Hermanson } \\
\text { (2004) }\end{array}$ \\
\hline Competence & $\begin{array}{l}\text { - Tidak ada rasa bersalah } \\
\text { - Mampu menemukan } \\
\text { celah } \\
\text { - Mampu menggunakan } \\
\text { - } \text { alat bantu illegal } \\
\text { - Memilih strategi }\end{array}$ & Ordinal & Mark (2012) \\
\hline Arrogance & $\begin{array}{l}\text { - } \text { Merasa superior } \\
\text { - } \text { Melindungi harga diri } \\
\text { - } \text { Butuh akan pengakuan }\end{array}$ & Ordinal & Mark (2012) \\
\hline
\end{tabular}

\section{d. Metode Analisis Data}

Pada penelitian ini analisis regresi linier berganda digunakan untuk menguji hipotesis. Peneliti menggunakan Aplikasi SPSS 24 digunakan untuk menganalisis data dipergunakan alat bantu software SPSS 24. Sebelum melakukan pengujian hipotesis, penelitian ini terlebih dahulu melakukan uji validitas, uji realibilitas dan uji asumsi klasik.

\section{a) Uji Validitas}

Dengan uji validitas, kita dapat mengetahui validitas dari kuesioner. Valid tidaknya suatu kuesioner dilihat dari pertanyaan dalam kuesioner dapat mengungkapan sesuatu yang diukur dalam kuesioner (Ghozali, 2016). Kriteria valid yaitu, nilai Corrected-Item Total Correlation > 0,3 item pertanyaan dikatakan valid.

\section{b) Uji Reliabilitas}

Menurut Ghozali (2016) suatu kuesioner memerlukan uji reliabilitas karena kuesioner mencerminkan atau mengindikasikan suatu variabel. 
Dikatakan handal atau reliabel jika jawaban seseorang akan suatu dinyatakan andal bila memiliki nilai Cronbach Alpha > 0,6.

\section{c) Uji Asumsi Klasik}

\section{Uji Normalitas}

Dengan uji normalitas kita dapat mengetahuib) Uji t

distribusi dari variabel penggangu atau residual dalam model regresi berdistribusi normal (Ghozali, 2016). Apabila nilai probabilitas $\geq$ 0,05 data dapat dinyatakan berdistribusi normal, sebaliknya jika nilai probabilitas $<0,05$ data dapat dinyatakan berdistribusi tidak normal.

\section{Uji heteroskedastisitas}

Dalam pengujian ini kita melihat ketidaksamaan varians dari residual suatu pengamatan dengan pengamatan lain dalam model regresi penelitian (Ghozali, 2016). Dikatakan baik ketika regresiLangkah-langkah Uji t: homoskesdastisitas atau tidak terjadi1. Formulasi $\mathrm{H}_{0}$ dan $\mathrm{H}_{1}$ heteroskedastisitas. Dalam penelitian ini menggunakan pendekatan scatterplots, yaitu $\mathrm{H}_{0}$ : menunjukkan tidak ada pengaruh memperhatikan plots dari sebaran residual dan variabel yang diprediksikan.

\section{Uji multikolinearitas}

Uji ini dimaksudkan untuk mengetahui hubungan antar variabel di dalam model regresi uji multikolinearitas (Ghozali, 2016). Kondisi yang baik ketika tidak ada hubungan antar variabel independen dalam model regresi penelitian. Batas nilai umum yang dipakai untuk menunjukkan adanya multikoliniearitas adalah nilai tolerance $\geq 0,10$ atau nilai $\mathrm{VIF} \leq 10$. Apabila VIF suatu model kurang dari 10 atau nilai tolerance lebih dari 0,10 maka model tersebut dinyatakan bebas dari kasus multikolinearitas.

\section{e. Uji Hipotesis}

a) Uji F pernyataan adalah konsisten dari waktu ke waktu. Kuesioner Uji $\mathrm{F}$ diperuntukan untuk melakukan uji hipotesis koefisien regresi secara bersamaan. Uji ini menguji apakah model dalam penelitian ini signifikan dan layak untuk memprediksikan variabel dependen.

Uji ini dimaksudkan untuk mengetahui pengaruh masing-masing pengaruh variabel independen terhadap variabel independen. Untuk menentukan diterima atau ditolaknya suatu hipotesis dapat dilihat dengan 2 cara. Pertama kita dapat membandingkan $\mathrm{t}$ hitung dengan $\mathrm{t}$ tabel. Cara yang kedua membandingkan taraf signifkan penelitian dengan nilai probabilitas.

secara parsial antara pressure, rationalization, opportunity, competence dan arrogance terhadap kecurangan akademik.

$\mathrm{H}_{1}$ : menunjukkan ada pengaruh secara parsial antara pressure, rationalization, opportunity, competence dan arrogance terhadap kecurangan akademik.

2. Level of Significant $(\alpha)$

Tingkat dari signifikan yang dipilih $10 \%$ $(\alpha=0,1)$

\section{Kriteria Keputusan}

$\mathrm{T}$ hitung dibandingkan dengan $\mathrm{t}$ tabel $(\alpha$ $=0,1, \mathrm{dk})$ dengan derajat kebebasan $(d k=n-k-1)$ pada taraf signifikansi $(\alpha=0,1)$ di mana $\mathrm{n}=$ banyaknya dan $\mathrm{k}=$ banyaknya variabel independen.

- Jika Sig > 0,1, maka $\mathrm{H}_{1}$ ditolak 
- Jika $\mathrm{Sig}<0,1$, maka $\mathrm{H}_{1}$ diterima

c) Koefisien Determinasi $\left(\mathrm{R}^{2}\right)$

Uji ini dimaksudkan untuk mengetahui mengenai variasi dari variabel independen dalam suatu model regresi (Ghozali, 2016). Nilai uji ini berkisar antara nol sampai satu. Semakin besar nilainya semakin banyak informasi yang dibutuhkan untuk menjelaskan variabel dependen.

\section{Hasil Dan Pembahasan}

Tabel 4.1 : Penyebaran Kuesioner

Keterangan

Jumlah Presentase

Dibagikan lewat form fisik

64

$52 \%$

Dibagikan lewat google form $48 \%$

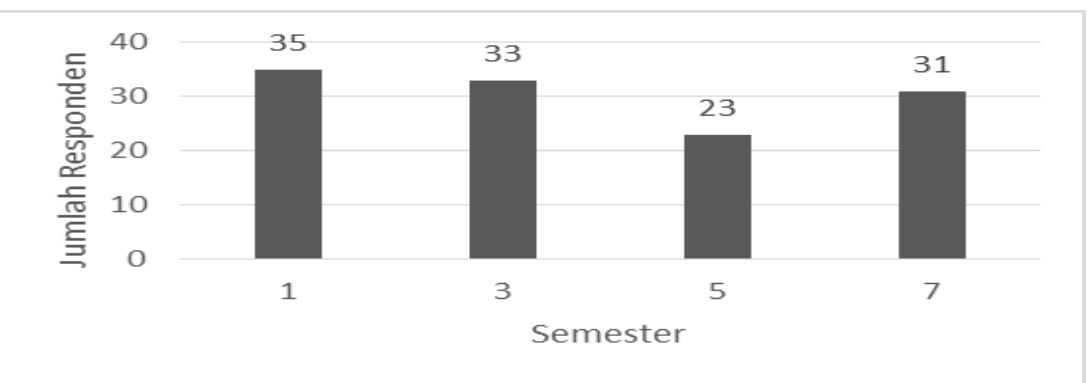

Gambar 4.1 Data Responden berdasarkan Semester

Mahasiswa Aktif yang yang menjadi responden dibagi dalam 4 semester yaitu $1,3,5$ dan 7 . Masing-masing jumlah dari tiap semesternya yaitu 35, 33, 23 dan 31 .

Data ini dapat

dilihat dalam Gambar 4.1

Gambar 4.2 Data Responden berdasarkan Jenis Kelamin

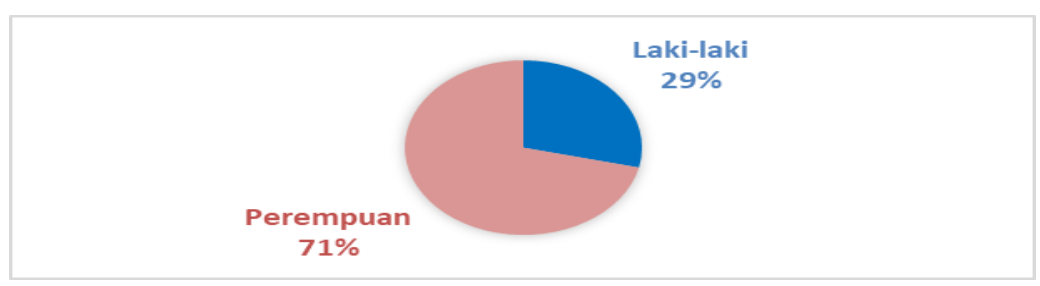

Pada gambar 4.2 data responden berdasarkan jenis kelamin. Responden dari kuesioner yang telah dibagikan didominasi oleh perempuan sesuai dengan kondisi mahasiswa FEB
Universitas Kristen Krida Wacana. Dari 122 responden terdapat 87 responden perempuan dan 35 responden laki-laki. 
Dikarenakan responden dari penelitian merupakan mahasiswa maka dari itu IPK juga menjadi salah satu acuan. Terdapat beberapa range untuk IPK sendiri yaitu N/A, 2,75-3,00, 3,01-3,25, 3,26-3,50 dan di atas 3,50. N/A ada karena pada mahasiswa semester 1 belum ada IPK dan ada beberapa responden yang tidak berkenan untuk memberitahu informasi mengenai IPK. Data dapat kita lihat dalam Gambar 4.3 berikut

Gambar 4.3 Data Responden Berdasarkan Range IPK

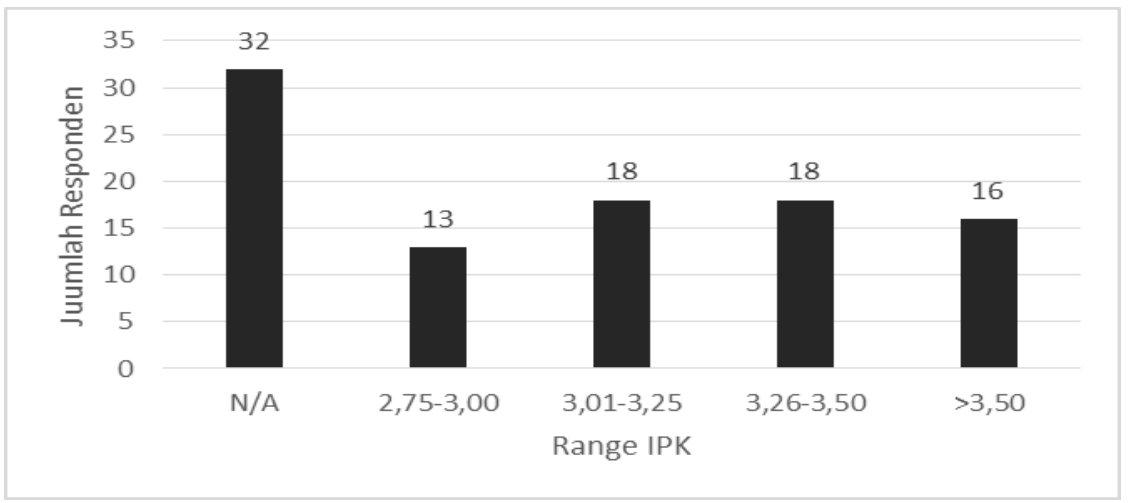

Sumber olah data: Microsoft Excel

\section{a. Hasil Uji Validitas}

Dengan uji validitas, kita dapat mengetahui validitas dari kuesioner. Valid tidaknya suatu kuesioner dilihat dari pertanyaan dalam kuesioner dapat mengungkapan sesuatu yang diukur dalam kuesioner (Ghozali, 2016). Kriteria valid yaitu, nilai Corrected-Item Total Correlation > 0,3 item pertanyaan dikatakan valid. Hasil uji validitas pada penelitian ini dapat dilihat pada tabel 4.1 berikut ini.

Tabel 4.2 : Hasil Uji Validitas

\begin{tabular}{|c|c|c|c|c|c|}
\hline Variabel & Item & $\begin{array}{c}\text { Corrected } \\
\text { Item- Total } \\
\text { Correlation }\end{array}$ & Variabel & Item & $\begin{array}{c}\text { Corrected } \\
\text { Item- Total } \\
\text { Correlation }\end{array}$ \\
\hline \multirow{5}{*}{$\begin{array}{c}\text { Kecurangan } \\
\text { Akademik }\end{array}$} & KA1 & 0.714 & Opportunity & OP1 & 0.556 \\
\hline & KA2 & 0.800 & & OP2 & 0.820 \\
\hline & KA3 & 0.619 & & OP3 & 0.770 \\
\hline & KA4 & 0.449 & & OP4 & 0.587 \\
\hline & KA5 & 0.680 & & OP5 & 0.730 \\
\hline \multirow{2}{*}{ Pressure } & PR1 & 0.425 & Competence & $\mathrm{CO} 1$ & 0.479 \\
\hline & PR2 & 0.527 & & $\mathrm{CO} 2$ & 0.569 \\
\hline
\end{tabular}




\begin{tabular}{|c|c|c|c|c|c|}
\hline & PR3 & 0.568 & & $\mathrm{CO} 3$ & 0.726 \\
\hline & PR4 & 0.538 & & $\mathrm{CO} 4$ & 0.371 \\
\hline & & & & $\mathrm{CO} 5$ & 0.763 \\
\hline \multirow{4}{*}{ Rationlization } & RA1 & 0.541 & Arrogance & AR1 & 0.439 \\
\hline & RA2 & 0.650 & & AR2 & 0.589 \\
\hline & RA3 & 0.477 & & AR3 & 0.355 \\
\hline & RA4 & 0.564 & & AR4 & 0.667 \\
\hline
\end{tabular}

Berdasarkan tabel 4.2 dapat disimpulkan bahwa item-item pernyataan yang digunakan dalam penelitian ini adalah valid. Hal ini dapat dilihat dari nilai masing-masing item pertanyaan memiliki nilai corrected item-total correlation lebih dari 0,3 .

\section{b. Uji Reliabilitas}

Menurut (Ghozali, 2016) kita perlu mengukur suatu kuesioner yang merupakan indikator dari variabel dengan uji relibialitas. Suatu kuesioner dikatakan handal atau reliabel jika jawaban seseorang akan suatu pernyataan adalah konsisten dari waktu ke waktu. Kuesioner dinyatakan andal bila memiliki nilai alpha Cronbach > 0,6. Hasil pengujian penelitian ini terlihat pada tabel 4.5 berikut ini.

Tabel 4.3 : Hasil Uji Reliabilitas

\begin{tabular}{cc} 
Variabel & $\begin{array}{c}\text { Cronbach's } \\
\text { Alpha }\end{array}$ \\
\hline KA & 0,838 \\
PR & 0,687 \\
RA & 0,737 \\
OP & 0,864 \\
CO & 0,793 \\
AR & 0,717
\end{tabular}

Sumber olah data: IBM SPSS 24

Berdasarkan Tabel 4.3 dapat disimpulkan keseluruhan variabel memiliki nilai Cronbach's Alpha lebih besar dari 0,60 yang berarti telah reliabel, sehingga layak digunakan menjadi alat ukur instrumen kuesioner dalam penelitian ini. 


\section{c. Hasil Uji Asumsi Klasik}

\section{Uji Normalitas}

Dengan uji normalitas kita dapat mengetahui distribusi dari variabel pengganggu atau residual dalam model regresi berdistribusi normal (Ghozali, 2016). Uji analisis statistik non-parametrik Kolmogorov $\bullet$ Jika nilai probabilitas $<0,1$ artinya data Smirnov yang digunakan untuk uji residual tidak berdistribusi normal. normalitas dalam IBM SPSS statistic 23. Jika nilai probabilitas $\geq 0,1$ artinya data Kriteria untuk pengambilan keputusannya: residual berdistribusi normal

\begin{tabular}{c|c|c|}
\multicolumn{2}{c}{ Tabel 4.4 Hasil Uji Normalitas } \\
$\mathrm{N}$ & Mean & .0000000 \\
\hline $\begin{array}{c}\text { Normal } \\
\text { Parameters }^{\text {a.b }}\end{array}$ & Std. Deviation & 2.01305597 \\
\cline { 2 - 3 } $\begin{array}{c}\text { Most Extreme } \\
\text { Differnces }\end{array}$ & Absolute & .060 \\
\cline { 2 - 3 } & Positive & .060 \\
\cline { 2 - 3 } & Negative & -.039 \\
\hline \multicolumn{2}{|r|}{ Test Statistic } & .060 \\
\hline \multicolumn{2}{|r|}{ Asimp. Sig. (2-tailed) } & $.200^{\text {c.d }}$ \\
\hline
\end{tabular}

Berdasarkan Tabel 4.4 didapatkan hasil Asymp.Sig (2-tailed) sebesar 0,200. Berdasarkan hasil tersebut dapat disimpulkan bahwa model regresi penelitian ini berdistribusi normal karena melebihi 0,1 .

\section{Uji Heteroskedasitas}

Untuk menguji apakah dalam model regresi terjadi ketidaksamaan varians dari residual satu pengamatan ke pengamatan yang lain digunakan uji heteroskedasitas (Ghozali, 2016). Dikatakan baik jika regresi homoskesdastisitas atau tidak

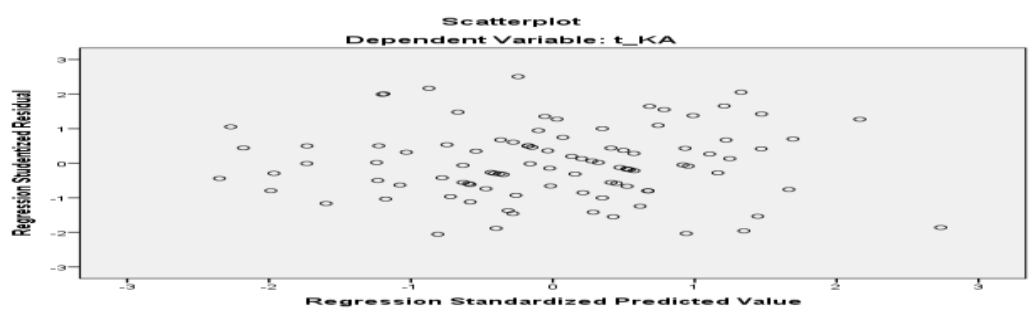

Gambar 4.4 Sebaran Scatterplot

terjadi heteroskedastisitas. Dalam penelitian ini menggunakan pendekatan scatterplots, yaitu memperhatikan plots dari sebaran residual dan variabel yang diprediksikan. Jika titik-titik menyebar secara acak serta tersebar merata di atas maupun di bawah angka 0 pada sumbu $\mathrm{Y}$, hal ini dapat disimpulkan bahwa tidak terjadi heteroskedastisitas pada model regresi. Hasil uji heteroskedastisitas pada penelitian ini dapat dilihat pada Gambar 4.4 berikut ini.Berdasarkan Gambar 4.4 di atas terlihat bahwa sebaran titik acak dan tidak membentuk suatu pola tertentu 
sehingga dapat disimpulkan tidak terjadi heteroskedastisitas.

\section{Uji Multikolinearitas}

Untuk menguji korelasi antar variabel independen dalam model regresi

digunakan uji multikolinearitas (Ghozali, 2016). Model

regresi yang baik seharusnya tidak terjadi korelasi di antara variabel independen. Batas nilai umum yang dipakai untuk menunjukkan adanya multikoliniearitas adalah nilai tolerance $\geq 0,10$ atau nilai VIF $\leq 10$. Apabila VIF suatu model kurang dari 10 atau nilai tolerance lebih dari 0,10 maka model tersebut dinyatakan bebas dari kasus multikolinearitas. Hasil uji multikolinearitas pada variabel independen dapat ditunjukkan pada Tabel 4.5 berikut:

Tabel 4.5 : Uji Multikolinearitas

\begin{tabular}{ccc} 
Variabel & Tolerance & VIF \\
\hline PR & 0,734 & 1,362 \\
RA & 0,492 & 2,032 \\
OP & 0,887 & 1,127 \\
CO & 0,572 & 1,748 \\
AR & 0,938 & 1,066
\end{tabular}

Berdasarkan Tabel 4.5 menunjukkan bahwa nilai tolerance dan VIF dari keempat variabel independen lebih dari 0,10 dan VIF kurang dari 10. Oleh karena itu dapat disimpulkan bahwa dalam model regresi tersebut terbebas dari masalah multikolinearitas, sehingga layak untuk digunakan.
Dalam pengujian hipotesis analisis regresi linear berganda digunakan untuk mengetahui pengaruh variabel independen yang terdiri dari pressure, opportunity, rationalization, competence dan arrogance terhadap perilaku kecurangan akademik. Hasil perhitungan regresi linier berganda dengan program SPSS disajikan pada Tabel 4.6

\section{d. Uji Hipotesis}

Tabel 4.6 : Hasil Analisis Regresi Berganda Unstandardized Coefficients

\begin{tabular}{llrrrr} 
Model & \multicolumn{2}{c}{ B } & \multicolumn{1}{c}{ Std. Error } & \multicolumn{2}{l}{ T } \\
\hline 1 & (Constant) & -.233 & 1.758 & -.133 & .895 \\
t PR & .471 & .119 & 3.952 & .000 \\
t RA & .200 & .148 & 1.350 & .180 \\
& t OP & .136 & .084 & 1.624 & .108 \\
& t CO & .361 & .113 & 3.192 & .002 \\
& t_AR & -.182 & .098 & -1.854 & .067
\end{tabular}

Berdasarkan Tabel 4.6 persamaan regresi linear berganda, yang dibaca adalah nilai dalam kolom B, baris pertama menunjukkan konstanta $(\alpha)$ dan baris 
selanjutnya menunjukkan koefisien variabel independen. Berdasarkan Tabel 4.6 model regresi yang digunakan adalah sebagai berikut.

$$
\begin{aligned}
& K A=-0,233+0,271 P R+0,200 R A+ \\
& 0,1360 P+0,361 C O-0,182 A R+0,1
\end{aligned}
$$

$$
\text { (4.1) }
$$

\section{Dimana:}

$$
\begin{array}{ll}
\mathrm{KA} & =\text { Kecurangan Akademik } \\
\mathrm{OP} & =\text { Opportunity } \\
\mathrm{B} & =\text { koefisien regresi } \\
\mathrm{CO} & =\text { Comptence } \\
\mathrm{PR} & =\text { Pressure } \\
\mathrm{AR} & =\text { Arrogance } \\
\mathrm{RA} & =\text { Rationalization } \\
\mathrm{e} & =\text { error }
\end{array}
$$

\section{Uji F}

Uji statistik $F$ pada dasarnya menunjukkan apakah secara keseluruhan semua variabel independen atau bebas yang mempunyai pengaruh terhadap variabel dependen/terikat (Ghozali, 2016). Untuk menentukan apakah hipotesis penelitian ditolak atau tidak, maka perlu dibandingkan antara nilai $\mathrm{F}$ hitung dengan $\mathrm{F}$ tabel, apakah nilai $\mathrm{F}$ hitung lebih besar dari nilai $F$ tabel atau sebaliknya. Hasil uji $F$ pada penelitian ini dapat dilihat pada Tabel 4.7 berikut ini.

Tabel 4.7 : Hasil Uji F

\begin{tabular}{ccccc} 
& & \multicolumn{1}{c}{ Mean } & & \\
& Model & Square & F & Sig. \\
\cline { 3 - 5 } & & & $0.000^{\mathrm{b}}$ \\
Regression & 70.549 & 16.502 & \\
Residual & 4.275 & &
\end{tabular}

Berdasarkan hasil perhitungan pada Tabel 4.7 hasil dari uji $\mathrm{F}$ signifikannnya sebesar 0,000 lebih kecil dari tingkat signifikan $10 \%$. Dengan demikian variasi nilai variabel bebas atau variabel independen dapat menjelaskan variasi nilai dependen. Sehingga variabel pressure, rationalization, opportunity, competence dan arrogance secara simultan atau keseluruhan berpengaruh terhadap perilaku kecurangan akademik.

\section{Uji t}

Uji t digunakan untuk mengetahui apakah variabel independen mempengaruhi variabel dependen secara satu per satu. Pada prosedur uji probabilitas statistik $\mathrm{t}$ atau nilai $\mathrm{p}$ kita hanya membandingkan nilai probabilitas $\mathrm{p}$ dengan nilai signifikansi $\alpha$ yang kita pilih. Bila sig. lebih dari 0,1 berarti variabel independen tidak berpengaruh terhadap variabel dependen. Sedangkan apabila sig. kurang dari 0,1 berarti variabel independen berpengaruh terhadap variabel dependen.

Berdasarkan tabel 4.6 dapat disimpulkan bahwa:

a. Konstanta sebesar -0,233 menunjukkan variabel-variabel independen (pressure, rationalization, opportunity, competence dan arrogance) diasumsikan tidak mengalami perubahan (konstan) maka bnilai Y (perilaku kecurangan akademik) adalah sebesar $-23,3 \%$.

b. Koefisien uji t pressure adalah 0,471 sedangkan nilai signifikansinya adalah 0,000 . Hasil signifikansi lebih kecil dari 0,1 yang berarti pressure memiliki pengaruh yang signifikan terhadap perilaku kecurangan akademik. Dengan kata lain hipotesis pertama diterima.

c. Koefisien uji t rationalization adalah 0,200 sedangkan nilai signifikansinya adalah 0,180. Hasil signifikansi lebih besar dari 0,1 yang berarti 
rationalization tidak memiliki pengaruh yang signifikan terhadap perilaku kecurangan akademik. Dengan kata lain hipotesis kedua ditolak.

d. Koefisien uji t opportunity adalah 0,136 sedangkan nilai signifikansinya adalah 0,108. Hasil signifikansi lebih besar dari 0,1 yang berarti opportunity memiliki pengaruh yang signifikan terhadap perilaku kecurangan akademik. Dengan kata lain hipotesis ketiga ditolak.

e. Koefisien uji $\mathrm{t}$ competence adalah 0,361 sedangkan nilai signifikansinya adalah 0,002. Hasil signifikansi lebih kecil dari 0,1 yang berarti competence memiliki pengaruh yang signifikan terhadap perilaku kecurangan akademik. Dengan kata lain hipotesis keempat diterima.

f. Koefisien uji t arrogance adalah 0,182 sedangkan nilai signifikansinya adalah 0,067. Hasil signifikansi lebih kecil dari 0,1 yang berarti arrogance memiliki pengaruh yang signifikan terhadap perilaku kecurangan akademik. Dengan kata lain hipotesis kelima diterima.

Tabel 4.8 : Hasil Uji Koefisien Determinasi

\begin{tabular}{|c|c|c|c|c|}
\hline Model & $\mathrm{R}$ & R Square & $\begin{array}{l}\text { Adjusted R } \\
\text { Square }\end{array}$ & $\begin{array}{c}\text { Std. Error of the } \\
\text { Estimated }\end{array}$ \\
\hline $\begin{array}{ll}1 \\
S\end{array}$ & $.690^{\beta}$ & .476 & .447 & 2.06762 \\
\hline
\end{tabular}

um

ber olah data: IBM SPSS 24

Dari Tabel 4.8 diketahui bahwa besarnya $R$ Square sebesar 0,476 atau $47,6 \%$. Hal ini berarti bahwa variabel pressure, rationalization, opportunity, competence dan arrogance mempengaruhi variabel perilaku kecurangan akademik sebesar 44,7\% Sedangkan sisanya $100 \%-47,6 \%=$ $52,4 \%$ dipengaruhi oleh variabel lain diluar model regresi ini.

\section{f. Pembahasan}

\section{Pengaruh Pressure Terhadap Perilaku Kecurangan Akademik}

Pengujian dilakukan melalui signifikansi koefisien regresi variabel pressure. Dari pengujian tersebut dapat berasal dari luar seperti dari orang tua, teman, maupun pihak pemberi beasiswa yang mengharuskan mendapatkan nilai indeks prestasi yang didapatkan nilai koefisien positif sebesar 0,471 dan sig-t sebesar 0,000 . Hal yang menunjukkan bahwa pressure berpengaruh secara signifikan terhadap perilaku kecurangan akademik mahasiswa Prodi Akuntansi Fakultas Ekonomi dan Bisnis Universitas Kristen Krida Wacana.

Hal ini menunjukkan bahwa dalam melakukan kecurangan akademik terdapat pressure baik itu dari internal maupun eksternal. Tekanan internal berupa motivasi yang berasal dari dalam diri sendiri. Sebagai contoh, nilai menjadi pencapaian pribadi yang dapat menjadi cerminan keberhasilan akademik atau studi mereka. Hal ini menyebabkan fokus dari mahasiswa itu bukan ilmu yang didapatkan melainkan nilai. Tekanan juga tinggi. Selain itu, mahasiswa yang banyak menghabiskan waktu di kegiatan diluar perkuliahan seperti bermain, nongkrong dan sebagainya sehingga 
waktu yang terbatas mendorong mahasiswa melakukan kecurangan akademik.Seorang anak selalu menunda pekerjaannya karena berbagai macam alasan. Tugas akan menumpuk tentunya dan ketika deadline sudah tiba biasanya cara yang paling sering dipakai adalah menyalin jawaban teman. Tak hanya dalam pengerjaan tugas saja namun dalam ujian pun hal ini sering terjadi. Hasil ini sejalan dengan penelitian Fitriani dan Baridwan (2012), Zaini, et al. (2015), Dewi (2016) dan Zamzam, et al. (2017). Hasil ini pun mendukung teori dari Fraud Pentagon. Dimana pressure merupakan salah satu faktor penyebab terjadinya kecurangan. Dan berdasarkan penelitian ini, semakin tinggi tekanan atau desakan yang ada atau diterima seseorang maka semakin besar pula kemungkinan tindak kecurangan akademik itu. Sebagai contoh ketika Pengaruh Rationalization Terhadap Perilaku Kecurangan Akademik

Pengujian dilakukan melalui signifikansi koefisien regresi variabel rationalization. Dari pengujian tersebut didapatkan nilai koefisien positif sebesar 0,200 dan sig-t sebesar 0,180 . Hal yang menunjukkan bahwa rationalization tidak berpengaruh secara signifikan anterhadap perilaku kecurangan akademik mahasiswa Prodi Akuntansi Fakultas Ekonomi dan Bisnis Universitas Kristen Krida Wacana.

Rasionalisasi adalah mekanisme pembenaran suatu perilaku yang tidak etis. Orang biasanya merasionalisasikan sesuatu hal yang menyimpang dari yang umum terjadi. Penelitian ini tidak konsisten dengan penelitian Nursani (2014) dan Dewi (2016). Hasil juga ini bertolak belakang dengan teori Fraud Pentagon. Dengan ini mendukung dari penelitian Zaini, et al. (2015) dan Zamzam, et al. (2017). Dimana rationalization merupakan salah satu faktor penyebab terjadinya kecurangan. Hal ini dikarenakan mahasiswa sudah mulai menyadari cara membedakan yang benar dan salah. Tidak merasionalkan perbuatan yang salah seperti kecurangan akademik. Entah itu dipengaruhi nilainilai budaya, keluarga ataupun agama dari individu tersebut.

\section{Pengaruh Opportunity Terhadap Perilaku Kecurangan Akademik} Pengujian dilakukan melalui signifikansi koefisien regresi variabel opportunity. Dari pengujian tersebut didapatkan nilai koefisien positif sebesar 0,136 dan sig-t sebesar 0,108 . Hal yang menunjukkan bahwa opportunity tidak berpengaruh secara signifikan terhadap perilaku kecurangan akademik mahasiswa Prodi Akuntansi Fakultas Ekonomi dan Bisnis Universitas Kristen Krida Wacana.

Hasil ini sejalan dengan penelitian Zaini, et al. (2015) dan Zamzam, et al. (2017). Hasil ini bertolak belakang dengan teori Fraud Pentagon. Dimana opportunity merupakan salah satu faktor penyebab terjadinya kecurangan.

Dapat diketahui dari penelitian ini bahwa mahasiswa Prodi Akuntansi tidak merasa memiliki kombinasi situasi dan kondisi yang memungkinkan dalam melakukan kecurangan akademik. Hal ini dikarenakan peraturan terkait kecurangan akademik dapat memberikan sanksi yang cukup berat, hal ini juga mengindikasikan bahwa peraturan terkait kecurangan akademik berjalan dengan baik. Pengawas ujian yang ketat, dosen memeriksa setiap tugas yang diberikan kepada mahasiswa, sehingga tidak memunculkan adanya kesempatan bagi mahasiswa untuk melakukan kecurangan akademik.

\section{Pengaruh Competence Terhadap Perilaku Kecurangan Akademik}

Pengujian dilakukan melalui signifikansi koefisien regresi variabel competence. Dari pengujian tersebut didapatkan nilai koefisien positif sebesar 0,361 dan sig-t sebesar 0,002. Hal yang menunjukkan bahwa competence berpengaruh secara signifikan terhadap 
perilaku kecurangan akademik mahasiswa Prodi Akuntansi Fakultas Ekonomi dan Bisnis Universitas Kristen Krida Wacana.

Hasil ini sejalan dengan penelitian Nursani (2014), Dewi (2016), Zamzam, et al., (2017) dan Hariri, et al. (2018). Hasil ini pun mendukung teori dari Fraud Pentagon. Dimana pressure merupakan salah satu faktor penyebab terjadinya kecurangan. Pengalaman juga memiliki peran penting. Semakin tinggi kemampuan dan banyak pengalaman mendorong perilaku kecurangan akademik. Tanpa adanya kemampuan tentu akan cukup beresiko jika melakukan tindakan kecurangan akademik. Maka dari itu kebanyakan dari pelaku perlu mempelajari celah yang ada sehingga aksinya dapat berjalan dengan mulus.

\section{Pengaruh Arrogance Terhadap Perilaku Kecurangan Akademik}

Pengujian dilakukan melalui signifikansi koefisien regresi variabel arrogance. Dari pengujian tersebut didapatkan nilai koefisien negatif sebesar $-0,182$ dan sig-t sebesar 0,067 . Hal yang menunjukkan bahwa arrogance berpengaruh secara signifikan terhadap perilaku kecurangan akademik mahasiswa Prodi Akuntansi Fakultas Ekonomi dan Bisnis Universitas Kristen Krida Wacana.

Hasil ini pun mendukung teori dari Fraud Pentagon. Dimana arrogance merupakan salah satu faktor penyebab terjadinya kecurangan. Untuk hasil negatif menunjukkan semakin kecil arogansi seseorang maka kecenderungan orang berbuat kecurangan akademik semakin besar. Sebaliknya orang-orang yang cukup arogan atau gengsi kecenderungan melakukan kecurangan akademik menjadi kecil. Hal ini dikarenakan orang dengan arogansi tinggi biasanya gengsi untuk melakukan hal-hal seperti menyontek, titip absen dan sebagainya. Dia merasa standarnya turun sama dengan orang lain.

\section{Simpulan dan Saran \\ a. Kesimpulan}

Berdasarkan hasil analisis dan pembahasan yang telah dilakukan yaitu mengenai pengaruh tekanan, kesempatan, rasionalisasi dan kemampuan terhadap perilaku kecurangan akademik maka dapat diberikan kesimpulan sebagai berikut:

1. Pressure berpengaruh positif terhadap perilaku kecurangan akademik mahasiswa Prodi Akuntansi Fakultas Ekonomi dan Bisnis Universitas Kristen Krida Wacana. Hal ini dikarenakan adanya tuntutan baik dari diri sendiri maupun orang lain sehingga mahasiswa merasa perlu memenuhi tuntutan tersebut. Ketidakmampuan unutk memenuhi tuntutan terkadang mejadi alasan utama untuk melakukan kecurangan akademik.

2. Rationalization tidak berpengaruh terhadap perilaku kecurangan akademik mahasiswa Prodi Akuntansi Fakultas Ekonomi dan Bisnis Universitas Kristen Krida Wacana. Hal ini dikarenakan mahasiswa sudah mulai menyadari cara membedakan yang benar dan salah. Tidak merasionalkan perbuatan yang salah seperti kecurangan akademik. Entah itu dipengaruhi nilai-nilai budaya, keluarga ataupun agama dari individu tersebut.

3. Opportunity tidak berpengaruh terhadap perilaku kecurangan akademik mahasiswa Prodi Akuntansi Fakultas Ekonomi dan Bisnis Universitas Kristen Krida Wacana. Hal ini dikarenakan adanya peraturan dengan sanksi yang cukup berat membuat mahasiswa berpikir dua kali untuk melakukan kecurangan akademik meskipun ada kesempatan di depan mata.

4. Competence berpengaruh positif terhadap perilaku kecurangan 
akademik mahasiswa Prodi Akuntansi Fakultas Ekonomi dan Bisnis Universitas Kristen Krida Wacana. Hal ini dikarenakan semakin banyak pengalaman seseorang maka dengan mudahnya dia dapat menyusun strategi khusus dalam melakukan kecurangan akademik sehingga dapat berjalan dengan lancar.

5. Arrogance berpengaruh negatif terhadap perilaku kecurangan akademik mahasiswa Prodi Akuntansi Fakultas Ekonomi dan Bisnis Universitas Kristen Krida Wacana. Hal ini dikarenakan orang dengan arogansi tinggi biasanya gengsi untuk melakukan hal-hal seperti menyontek, titip absen dan sebagainya. Dia merasa standarnya turun sama dengan orang lain.

\section{b. Keterbatasan}

Dalam penelitian ini terdapat beberapa keterbatasan yang dimiliki peneliti. Penyebaran kuesioner yang tidak konsisten dikarenakan perbedaan jadwal kuliah semester 7 dengan semester lainnya.

\section{c. Saran}

Berdasarkan hasil penelitian ini, maka penulis dapat memberikan saran sebagai berikut:

1. Penelitian selanjutnya diharapkan mengumpulkan sampel dengan jumlah yang lebih merata sehingga hasil penelitian lebih menjelaskan keadaan yang sebenarnya.

2. Untuk pembagian kuesioner lebih baik konsisten pada satu metode. Dan sangat disarankan penggunaan google form karena selain biaya yang lebih rendah, responden juga lebih serius dalam pengisian kuesioner

3. Penelitian selanjutnya sebaiknya menambah variabel independen lain yang tidak dijelaskan pada penelitian. Sehingga dapat meneliti faktor lain yang mempengaruhi perilaku kecurangan akademik.

\section{Daftar Pustaka}

Achsin, M. \& Cahyaningtyas, R. I., 2016. Studi Fenomologi Kecurangan Mahasiswa dalam Pelaporan Pertanggungjawaban Dana Kegiatan Mahasiswa: Sebuah Realita dan Pengakuan. Jurnal Ilmiah Mahasiswa FEB Universitas Brawijaya, 3(2).

Ajzen, I., 1991. The Theory of Planned Behavior. Organizational Behavior and Human Decision Processes, 50(2), pp. 179-211.

Albrecht, W. S., 2003. Fraud Examination. South-Western: Cengage Learning.

Albrecht, W. S., Albrecht, C. O., Albrecht, C. C. \& Zimbelman, M. F., 2011. Fraud Examination. 4th ed. South-Western: Cengage Learning.

Anderman, E. M., 2002. School Effects on Psychological Outcomes during Adolescence. Journal of Educational Psychology, Volume 94(4), pp. 795-809.

Cerdán, A. G., 2017. CogniFit. [Online] Available at: https://blog.cognifit.com/arrogan cel [Accessed 5 September 2018].

Cizek, G. J., 2003. Detecting and preventing classroom: promoting integrity in assessment. California: Corwin Press.

Davis, S. F., Drinan, P. F. \& Gallant, T. B., 2009. Cheating in School: What We Know and What We Can do. Chiscester: Wiley Blackwell.

Dewi, P., 2016. Perilaku Kecurangan Akademik Pada Mahasiswa S1, S2, dan S3 Jurusan Akuntansi FEB UB Berdasarkan Konsep Diamond Fraud. Jurnal Ilmiah Mahasiswa Fakultas Ekonomi dan Bisnis Universitas Brawijaya, 4(2). 
Eckstein, M. A., 2003. Combating Academic Fraud: Towards a Culture of Integrity. Paris: International Institute for Educational Planning.

Eriksson \& McGee, 2015. Academic dishonesty amongst Australian Crimiinal Justice and Policing University Students: Individual and Contextual Factors. International Journal for Educational Integrity, 3(2).

Fitriani \& Baridwan, 2012. Perilaku Kecurangan Akademik Mahasiswa Akuntansi: Dimensi Fraud Triangle. Jurnal Akuntansi Multiparadigma, 3(2), pp. 166331.

Ghozali, I., 2016. Aplikasi Analisis Multivariate dengan Program SPSS 23. Semarang: Badan Penerbit Universitas Diponegoro.

Hariri, Pradana, A. W. S. \& Rahman, F., 2018. Mendeteksi Perilaku Kecurangan Akademik dengan Perspektif Fraud Diamond Theory. Jurnal Ketahanan Pangan, 2(1), pp. 1-11.

Jogiyanto, H. M., 2010. Metodologi Penelitian Bisnis. Yogyakarta: BPFE.

Lano, P. F., 2015. Fungsi Kepemimpinan untuk Mengurangi Sikap Arogansi Pegawai. Jurnal Ilmu Sosial dan Ilmu Politik, 4(1), pp. 74-81.

Marks, J., 2010. Drillie. [Online] Available at: http://www.drlillie.com/a541/arti cles/risk8115.pdf [Accessed 26 Agustus 2018].

Marks, J., 2012. Fraud Conference.

[Online]

Available at:

http://www.fraudconference.com /uploadedFiles/Fraud Conferenc
e/Content/Course-

Materials/presentations/23rd/ppt/

10C-Jonathan-Marks.pdf

[Accessed 26 Agustus 2018].

Marks, J., 2012. The Mind Behind The

Behind The Fraudsters: Key

Behavioral and Environmental

Elements. [Online]

Available at:

http://www.fraudconference.com /uploadedFiles/Fraud_Conferenc e/Content/Course-

Materials/presentations/23rd/ppt/ 10C-Jonathan-Marks.pdf [Accessed 24 Agustus 2018].

Marks, J., 2012. The Mind Behind The Fraudsters Crime: Key Behavioral And Environmental Elements Discussion Leader: Crowe Horwarth. Orlando, Crowe Hortwarth.

McCabe, D. L. \& Trevino, L. K., 1997. Individual and Contextual Influences on Academic Dishonesty: A Multicampus Investigation. Research in Higher Education, 38(3), pp. 379-396.

Mulyawati, H., 2010. Pembelajaran Studi Sosial : Tujuan Pengajaran Studi Sosial, Mendidik Anak Menjadi Warga Negara yang Baik. Bandung: Alfabeta.

Nursani, R., 2014. Perilaku Kecurangan Akademik Mahasiswa: Dimensi Diamond Fraud. Jurnal Ilmiah Mahasiswa Fakultas Ekonomi dan Bisnis Universitas Brawijaya, 2(2).

Primatasari, D. N., Suhendro \& W., E. M., 2017. Perilaku Kecurangan Akademik Mahasiswa Akuntansi dengan Menggunakan Dimensi Fraud Diamond. Jurnal Akuntansi dan Sistem Teknologi Informasi, Volume 13, pp. 118126. 
Pudjiastuti, E., 2012. Hubungan "Self Efficacy" dengan Perilaku Mencontek Mahasiswa Psikologi. Mimbar, pp. 28(1): 103-112.

Rangkuti, A. A., 2011. Academic cheating behaviour of accounting students: A case study in Jakarta State University. Educational

12th Annual South Florida Education Research Conference, pp. 189194.

Akuntansi dengan Menggunakan Konsep Triangle Fraud. Jurnal Ilmiah Mahasiswa FEB.

Sekaran, U. \& Bogey, R., 2013. Research Methods for Business: A SkillBuilding Approach. 6 ed. New York: Wiley.

Stone, T. H., Jawahar, I. \& Kisamore, J., 2010. Predicting Academic Misconduct Intentions and Behavior Using the Theory of Planned Behavior and Personality. Basic and Applied Social Psychology, pp. 35-45.

Sugiyono, 2009. Metode Penelitian Kuantitatif, Kualitatif dan $R \& D$. Bandung: Alfabeta.

Susanti, A., 2017. PT Media Nusantara CItra. [Online]

Available at: https://news.okezone.com/read/2

Zaini, Carolina \& Setiawan, 2015. Analisis Pengaruh Diamond Fraud dan Gone Theory Terhadap Academic Fraud (Studi Kasus Mahasiswa Akuntansi SeMadura). Simposium Nasional Akuntansi XVIII, pp. 1-20. integrity: Culture and values. Proceedings 5th Asia Pacific Conference on Educational Integrity, Issue 2011, pp. 105109.

Robinson, M., 2013. Academic Dishonesty: A Guide for Digital Instructors. Proceedings of the

Santoso, M. H. \& Adam, H., 2014. Analisis Perilaku Kecurangan Akademik pada Mahasiswa

017/01/11/65/1588492/pendidika n-belum-berhasil-ciptakanmoral-baik

Wolfe, D. T. \& Hermanson, D. R., 2004. The Fraud Diamond: Considering the Four Elements of Fraud. The CPA Journal, 74(12), pp. 38-42.

Wood, G. \& Warnken, P., 2004. Managing Technology, Academic Original Sin: Plagiarism, The Internet, and Librarians. Journal of Academic Librarianship, 30(3), pp. 237242.

Yudiana, A. P. \& Lastanti, H. S., 2016. Analisis Pengaruh Dimensi Fraud Diamond Terhadap Perilaku Kecurangan Akademik Mahasiswa Fakultas Ekonomi. Seminar Nasional Fakultas Ekonomi UNIBA Surakarta, 2(1), pp. 412-422.

Zamzam, I., Mahdi, S. A. \& Ansar, R., 2017. Pengaruh Diamond Fraud dan TIngkat Religiuitas terhadap Kecurangan Akademik. Jurnal Ilmiah Akuntansi Peradaban, 3(2). 